\title{
Comments on the Paper "Is the Sea Level Stable at Aden, Yemen?" by Albert Parker and Clifford D. Ollier in Earth Systems and Environment (Volume 1, December 2017)
}

\author{
Lesley Rickards ${ }^{1}$ (D)
}

Received: 21 December 2017 / Accepted: 30 January 2018 / Published online: 12 February 2018

(c) The Author(s) 2018. This article is an open access publication

\begin{abstract}
This short note provides comments and a response to the paper published in Earth Systems and Environment by Albert Parker and Clifford D. Ollier (Volume 1, December 2017) entitled "Is the Sea Level Stable at Aden, Yemen?"
\end{abstract}

Keywords Sea level database $\cdot$ Tide gauge records $\cdot$ Tide gauge benchmarks $\cdot$ Openly accessible data

We refer to a recent paper "Is the Sea Level Stable at Aden, Yemen?" published in Earth Systems and Environment by Albert Parker and Clifford D. Ollier (Volume 1, December 2017); this comment is a response to it. The authors look at the sea level records from Aden, Karachi and Mumbai in the dataset of the Permanent Service for Mean Sea Level (PSMSL, www.psmsl.org) which is hosted by the National Oceanography Centre (NOC, www.noc.ac.uk) in the United Kingdom.

The paper comes to several conclusions and makes certain assertions:

1. That the long records at Aden, Karachi and Mumbai, spanning about a century each, are in fact composites constructed from sections of data of several decades each obtained from different tide gauges at different times.

This is of course correct. The sections are an inevitable consequence of authorities having operated different tide gauges in different parts of their records.

2. That there are gaps between the sections of data. The authors ask 'How can we perform a proper alignment

Lesley Rickards

ljr@noc.ac.uk

1 Permanent Service for Mean Sea Level, National Oceanography Centre, Joseph Proudman Building, 6

Brownlow Street, Liverpool L3 5DA, UK of data when there are gaps of years and the tide gauge has been moved, destroyed, or replaced?'

Tide gauges measure sea level relative to marks on the nearby land called 'benchmarks'. Sometimes these marks are destroyed due to harbour developments and new ones are installed. In some ways, the benchmarks are more important than the tide gauges themselves. The answer to the above question is that it is essential for the PSMSL to have the best possible documentation of the history of the different marks and their heights relative to each other. In that way, sections of data can then be combined reliably. Nevertheless, it is clearly more desirable to have long, continuous records rather than ones with many gaps, as all sea level scientists recognise.

3. The authors show examples of sea levels in different sections of data measured to their individual datums (or benchmarks). Such data are known as Metric information in PSMSL terminology (these terms are described fully on the PSMSL website www.psmsl.org). An important job of the PSMSL is to attempt to join these separate sections together to obtain long records, as continuous as possible and measured to the same datum, suitable for scientific analysis. Such adjusted records are known as Revised Local Reference (RLR) records. The authors also show examples of the RLR records corresponding to the Metric data from the sites in question, indicating the adjustments made by the PSMSL. 
The essential point is that the adjustment is never 'arbitrary' [a word used many times by Parker and Ollier (2017)] or 'suspicious' (another word they use), but is based on documentation of benchmark heights held by the PSMSL stretching back many years. This situation contrasts with the arbitrary datum decisions introduced by Parker and Ollier (2017) based on no documented information at all. In fact, the PSMSL holds Metric information for many stations for which it cannot make the adjustments to convert them to RLR because the essential documentation is lacking.

4. The different data used at different points in the history of a station are the main reason for the RLR adjustments. However, there is a second reason. This stems from some sections of data being Mean Tide Level (MTL) instead of Mean Sea Level (MSL). MSL is the arithmetic average of sea level recorded over a period such as a month or a year, while MTL is the average of high and low waters in that time. They are not the same quantities and an adjustment to convert MTL to MSL is required, based on the knowledge of the ocean tide at that location. Parker and Ollier (2017) refer to this as a 'subjective' correction, which is not the case, because it can be estimated very well (Woodworth 2017). Nevertheless, the magnitude of the adjustment is given in the online documentation and it need not be employed by analysts of the dataset if authors choose not to.

As far as Aden, Karachi and Mumbai are concerned, the PSMSL website states clearly that sections of the RLR records were adjusted for the MTL-MSL difference. These adjustments were 16, 10 and $31 \mathrm{~mm}$ for Aden (1937-1956), Karachi (1937-1948) and Mumbai (1931-1958), respectively. Again, if analysts such as Parker and Ollier do not believe that these adjustments are reasonable, they do not have to make use of them.

5. The authors point out that the adjustments for some sections of data have been re-assessed in recent years, resulting in versions of the RLR records that differ from those made available previously.

It is an ongoing job of the PSMSL to determine whether adjustments are correct, especially when new documentation becomes available or if there is a re-analysis of the existing documentation. For example, in the cases of Aden and Karachi, there were assessments of the benchmark histories several years ago, following installation of new gauges at these locations by NOC and international colleagues (Woodworth et al. 2009). Versions of the PSMSL dataset, archived annually since 2011 , can be found on its website from which the date of changes to any station record can be readily identified.
The Parker and Ollier (2017) paper presents many different numbers gleaned from different sources. There is only one point in it (in Sect. 3.1) that has major importance for the sea level record at Aden. That is to do with the most recent of the PSMSL's assessments of the benchmark history at Aden for the earliest years in its record. That assessment was made by the PSMSL in 2013 and resulted in the RLR sea levels for the first 15 years of data (1879-1893) being increased, back to where the PSMSL had determined them to be prior to an earlier assessment in 2008. It was decided that the assessment of the documentation in 2008 had concluded, incorrectly, that the 1879-1893 levels should have been lower. The conclusion of the recent assessment in 2013 was consistent with the findings of 2 , but was not a consequence of Hogarth's (Hogarth 2014) work, as Parker and Ollier imply.

The most recent changes are mentioned on the PSMSL website. They resulted in a decrease (and not an increase) in the estimated 19th-20th century rate of sea level change at Aden, contrary to the impression one might obtain from the Parker and Ollier (2017) paper. The reasons for the 2013 assessment were explained in an email to Albert Parker on 19 September 2017 following an enquiry from him on 11 September. We note that the Parker and Ollier paper had a submission date of 17 September.

It is perfectly possible that the adjustments for sections of data may be re-assessed in the future and, as a result, the RLR records will change. This applies to Aden which is a long record with historical documentation that could be clearer in parts (hence the mistake in 2008). It also applies to every other record in the dataset. It is the PSMSL's ongoing responsibility since 1933 to undertake such assessments from time to time. In the case of Aden, the recent discovery of much earlier sea level data from the mid-nineteenth century will result before long in another assessment of the history of this interesting record.

6. The most serious assertion of the authors is that the PSMSL conspires to make RLR adjustments in an arbitrary way such that sea level appears to be rising faster than it really is. This assertion was picked up by several websites that are keen to comment negatively on climate-related research. It is an assertion that is completely unwarranted. The PSMSL aims to provide reliable records for research that are as long and continuous as possible, whether they happen to go down (as in Scandinavia) or up.

To summarise, the Parker and Ollier (2017) paper draws all its data from PSMSL, both the uncorrected (Metric) and corrected (RLR) data. It would not have been possible for them to publish their paper without full access to all the data and information on various corrections applied that the 
PSMSL makes available. This demonstrates the value of the PSMSL database, in which all data are open to full scientific scrutiny and scientific debate.

Open Access This article is distributed under the terms of the Creative Commons Attribution 4.0 International License (http://creativeco mmons.org/licenses/by/4.0/), which permits unrestricted use, distribution, and reproduction in any medium, provided you give appropriate credit to the original author(s) and the source, provide a link to the Creative Commons license, and indicate if changes were made.

\section{References}

Hogarth P (2014) extended tide gauge data. supplementary note 4: indian ocean (2014, updated January 2016). http://www.psmsl
.org/products/author_archive/Indian_Ocean_Tidal_Data_and_ References_3d.pdf. Document downloaded 17 Dec 2017

Parker A, Ollier CD (2017) Is the sea level stable at aden, yemen?". Earth Syst Environ 1:18. https://doi.org/10.1007/s4174 $8-017-0020-z$

Woodworth PL (2017) Differences between mean tide level and mean sea level. J Geodesy 91:69-90. https://doi.org/10.1007/s0019 0-016-0938-1

Woodworth P, Foden P, Pugh J, Matthews A, Aarup T, Aman A, Nkebi E, Odametey J, Facey R, Esmail MYA, Ashraf M (2009) Insight into long term sea level change based on new tide gauge installations at Takoradi, Aden and Karachi. Int Hydrogr Rev 1:18-23 